腫瘍の肉眼形態からみた膵管癌の進展様式

一切除症例の組織学的検討一

\begin{tabular}{|c|c|c|c|c|c|c|c|c|c|c|c|c|}
\hline & & & . & 十大学 & 第 1 & 外和 & 主伯 & : 中瀬 & 明老 & & & \\
\hline 村 & 勝 & 洋 & 中 & 川 & 正 & 久 & 内 & 藤 & 篤 & 矢 & 野 & 諴 司 \\
\hline & 聱 & 根 & 長 & 見 & 晴 & 彦 & 寺 & 本 & 睦 & 柏 & 田 & 順一郎 \\
\hline L & & 康 & 瀬 & 下 & 達 & 之 & 上 & 垣 & 賢 & 中 & 瀬 & \\
\hline
\end{tabular}

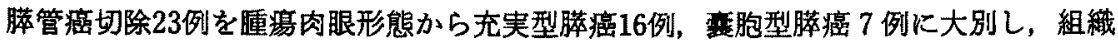
学的進展様式から retrospective に妥当な衍式や予後規定因子を検討した，前者は乳頭 管状一管状腺癌であり膵内で著明な静脈，神释，リンパ管浸潤が見られたが，腫煬辺縁 から3cm 離せば脺断端に浸潤はなかった，後方浸潤る著明で萃外神释叢を含めた十分な 郭清を要するが，組織学的に ew (十)例が多かった、リンハ節転移も高率であり， $\mathbf{R}_{2}$ 郭 清を要する。一方, 後者はいわゆる粘液産生癌であり，勝内外での浸潤は少なく $\mathrm{R}_{1}$ 郭清 で十分である．前者を中心に血管合併切除を要する症例が多かったが，血管の肉眼と組 織学的浸潤度に差があるので慎重に判断すべきである。切除例の遠隔成績は前者は不良 で後者は極めて良好であった。この差を生した最大の要因はv因子と $\mathrm{rp}$ 因子と思われ た．前者の肉眼的治庱切除症例では ew 因子が予後規定因子となっていた.

索引用語：充実型膵癌, 烡胞型膵癌, 組織学的進展様式, 膵癌手術術式, 予後規定因子

\section{緒言}

膵癌の手術成績が他臓器のそれに比べて悪い原因の ひとつにその複雑な進展様式があげられる。通常, 手 術術式の選択は画像を中心とする街前診断や術中迅速 病理診断などを参考にして，術中肉眼所見をるとに その進展様式を判断して決定される。そこで，当教室 で行った膵管癌に対する膵切除症例について組織学的 進展様式を検討し，術前あるいは術中に診断した肉眼 所見，特に尰瘍の肉眼形態からみた妥当な手術術式の 選択中予後規定因子について retrospectiveに険討し た.

\section{対象症例书よU゙方法}

以下の用語, 略語は膵癌取扱い規約（日本膵倵学会 編，第 3 版，1986年：以下，取扱い規約 $)^{11}$ に従った。

過去10年間に当数室で開腹手術した膵管癌は40例で ある.この5ち，23例に膵切除を行い，17例は非妡除 に終った。これらの症例を術前画像診断を加味して診 た術中腫崲肉眼形態により，硬く充実性のbのを充実 型（solid type），变胞性のむのを型胞 (cystic type)
として大別すると以下のごとくであった。

\section{I. 充実型膵癌切除症例（表 1)}

16例がこれに分類され，腫瘍の肉眼的性状は腫瘤型 が14例て，2 例が䏽外腫瘤形成型であった。膵頭部癌 10例，体尾部癌 5 例，全体癌 1 例で，大きさは $T_{2-4}$ で あり, Stageは11例がIVで残りは山であった。門脈に $\mathrm{PV}_{2}$ 以上の浸潤が12例に，また上腸間膜動脈, 腹腔動脈 およびその幹枝に $\mathrm{A}_{2}$ 以上の浸潤が 8 例にみられ, これ らの血管はすへて合併切除して血行再建した. Standard Operation（摽準手術，以下Std）による pancreatoduodenectomy (膆頭十二指腸切除, 以下 PD) 1 例，リンパ節郭清程度 $\mathrm{R}_{2-3}$ の Extended Operation （扗大手術，以下 Exd）によるPD 6 例， $\mathrm{R}_{2-3}$ の Exd total pancreatectomy（桠全摘, 以下 TP) 4 例, $\mathrm{R}_{2}$ の Exd distal pancreatectomy (膵尾側切除, 以下 DP) (subtota) 2 例，以上の13例は取扱い規約による条件 に照らして肉眼的治瘦切除であった. 残る 3 例のちち， 应例 9 ，10は别離面漫閏 $\mathrm{EW}(+)$, 肝転移 $\mathrm{H}_{1}$ （㬳転 移紧は亜区域切除）のため，症例16は下大静脈漫潤巣 る合併切除する R1 Exd TPを行ったが EW (十)の ために肉眼的非治掼切除となった。

1990年 9月11日受付 1991年4月27日採用 


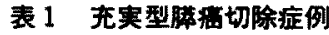

\begin{tabular}{|c|c|c|c|c|c|c|c|c|c|c|c|}
\hline \multirow{2}{*}{\multicolumn{2}{|c|}{ 庭 例 }} & \multicolumn{4}{|r|}{ 肉 } & \multirow[b]{2}{*}{ 大きさ } & \multicolumn{2}{|l|}{ 所 見 } & \multicolumn{2}{|r|}{ 手街"2 } & \multirow{2}{*}{ 慢 } \\
\hline & & & 晨的性 & 壮 & 占居部位 & & 浸 閵 血 管 & Stage & $R \cdot$-number & 䐙 切 除 & \\
\hline 1. 77 & 男 & 戛 & 鵉 & 型 & $\mathrm{Ph}$ & $T_{3}$ & \multirow[b]{2}{*}{$\mathrm{PVp}_{2}$} & III & $\mathrm{R}_{1}$ & Std PD & 螵死(11力月) \\
\hline 2. 74 歳 & 女 & 堹 & 窟 & 型 & $\mathrm{Ph}$ & $\mathrm{T}_{2}$ & & III & $\mathbf{R}_{\mathbf{2}}$ & Exd TP & 癌死（４カ月 \\
\hline 3. 65 瓷 & 男 & 尰 & 露 & 型 & Ptb & $\mathrm{T}_{4}$ & $\begin{array}{l}\text { Asp }_{3}, \text { Asm }_{2} \\
\text { Ace }_{1}, \text { Ach }_{1}\end{array}$ & N & $\mathbf{R}_{\mathbf{2}}$ & Exd DP (subtotal) & 聇死 ( 1 年 4 力月) \\
\hline 4. 62 筬 & 女 & 尰 & 痬 & 型 & Phb & $T_{2}$ & $\begin{array}{l}\text { Asm }_{3}, \text { PVp }_{3} \\
\text { PV }\end{array}$ & $\mathbf{N}$ & $\mathbf{R}_{\mathbf{3}}$ & Exd TP & $\begin{array}{l}\text { 䛞不全死 } \\
\text { (睧肪訮，3 カ月) }\end{array}$ \\
\hline 5. 65 㢼 & 女 & 㕎 & 霸 & 型 & Phb & $T_{3}$ & $\begin{array}{l}\text { Ace }_{2} \text { Ach }_{3}, \text { Asp }_{2} \text { Asm } \\
\text { PVp, }\end{array}$ & $\mathbf{v}$ & $\mathbf{R}_{\mathbf{3}}$ & $\begin{array}{c}\text { Exd PD } \\
\text { (Exd TP+尾側愺自家移植) }\end{array}$ & 健在 ( 2 年11力月) \\
\hline 6. 75 紫 & 女 & 舼 & 瘦 & 型 & Pbth & $\mathrm{T}_{4}$ & $\begin{array}{l}\mathrm{Asm}_{3}, \mathrm{Asp}_{3}, \\
\mathrm{PVP}_{3}, \mathrm{PVsm}, \mathrm{PV} \mathrm{sp}_{3}\end{array}$ & N & $\mathbf{R}_{\mathbf{3}}$ & Exd TP & $\begin{array}{l}\text { 心不舍死 } \\
\text { (脂肪, } 4 \text { 力月) }\end{array}$ \\
\hline 7. 67 留 & 男 & 锤 & 䆛 & 型 & $\mathrm{Ph}$ & $\mathrm{T}_{2}$ & & III & $\mathbf{R}_{\mathbf{2}}$ & Exd PD & 揵在 ( 2 年 5 力月) \\
\hline 8. 63 敛 & 男 & 酐外相 & 重窝形 & 如成型 & $\mathrm{Ph}-\mathrm{b}$ & $\mathbf{T}_{2}$ & $\begin{array}{l}\mathrm{Ace}_{2}, \mathrm{Ach}_{3}, \mathrm{Asp}_{1} \\
\mathrm{PV} \mathrm{p}_{3}, \mathrm{PVsm}, \mathrm{PV} \mathrm{sp}_{2}\end{array}$ & N & $\mathbf{R}_{3}$ & $\begin{array}{c}\text { Exd PD } \\
\text { (Exd TP+尾僋譄自家移植) }\end{array}$ & 痋死 ( 1 年 5 力月) \\
\hline 9. 63 藏 & 女 & 腩外盘 & 重渎形 & 殁成型 & Ptb & $\mathrm{T}_{4}$ & Asp $_{3}, \mathrm{PVsp}_{3}$ & $\mathbf{N}$ & $\mathbf{R}_{\mathbf{0}}$ & 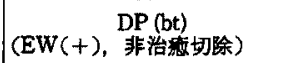 & 㾞死 (4力月) \\
\hline 10. 59 巂 & 女 & 踵 & 筍 & 型 & Pt & $T_{4}$ & & $\mathbf{N}$ & $\mathbf{R}_{\mathbf{0}}$ & 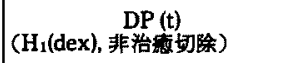 & 密死( 4 力月) \\
\hline 11. 74歳 & 男 & 踵 & 庭 & 型 & $\mathrm{Ph}$ & $T_{2}$ & $\mathrm{PVsm}_{2}$ & $\mathbf{N}$ & $\mathbf{R}_{\mathbf{z}}$ & Exd PD & 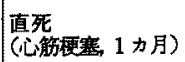 \\
\hline 12. 63 藏 & 女 & 連 & 啇 & 型 & $\mathrm{Ph}$ & $T_{2}$ & $\mathrm{PVP}_{1}, \mathrm{PVsm}_{2}$ & III & $\mathbf{R}_{\mathbf{3}}$ & $\begin{array}{c}\text { Exd PD } \\
\text { (Exd TP+尾側旆自家移植) }\end{array}$ & 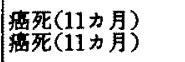 \\
\hline 13. 73藏 & 女 & 璉 & 瘤 & 型 & $\mathrm{Pbh}$ & $T_{2}$ & $\begin{array}{l}\mathrm{Ace}_{3}, \mathrm{Ach}_{3}, \mathrm{Asm}_{2} \\
\mathrm{Asp}_{3}, \mathrm{PV}_{\mathrm{p}_{3}, \mathrm{PVsm}}\end{array}$ & $\mathbf{V}$ & $\mathbf{R}_{\mathbf{2}}$ & Exd TP & 舟死 ( 4 力月) \\
\hline 14. 65 歳 & 男 & 尰 & 雷 & 型 & $\mathrm{Pb} \cdot \mathrm{t}$ & $\mathrm{T}_{4}$ & $\begin{array}{l}\mathrm{Ace}_{2} \mathrm{Ach}_{3}, \mathrm{Asp}_{3} \\
\mathrm{PV}_{3 p_{3}}\end{array}$ & $\mathbf{v}$ & $\mathbf{R}_{\mathbf{z}}$ & Exd DP (subtotal) & 癌死( 8 力月) \\
\hline 15. 78 咸 & 女 & 䵯 & 虚 & 型 & $\mathrm{Ph}$ & $\mathbf{T}_{3}$ & $\mathrm{PV}_{\mathrm{p}_{2}, \mathrm{PV}_{\mathrm{sm}}}$ & III & $\mathbf{R}_{\mathbf{2}}$ & Exd PD & 健在 (4力月) \\
\hline 16. 60 慼 & 男 & 踵 & 聲 & 型 & Phb & $T_{4}$ & $\mathrm{PV}_{\mathrm{p}}, \mathrm{ICV}_{2}{ }^{* 1}$ & $\mathbf{v}$ & $\mathbf{R}_{\mathbf{1}}$ & $\begin{array}{c}\text { Exd TP } \\
(\mathrm{EW}(+), \text { 非治被妡除) }\end{array}$ & 生存 ( 1 力月) \\
\hline
\end{tabular}

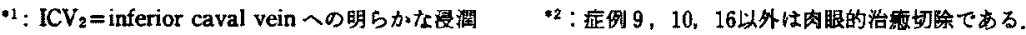

表 2 面胞型腆蕰切除症例

\begin{tabular}{|c|c|c|c|c|c|c|c|c|c|}
\hline \multirow{2}{*}{\multicolumn{2}{|c|}{ 症 例 }} & \multicolumn{2}{|r|}{ 肉 } & 眼 & \multicolumn{2}{|l|}{ 見 } & \multicolumn{2}{|r|}{ 手 術*2 } & \multirow{2}{*}{ 転 } \\
\hline & & 肉眼的性状 & 占居部位 & 大きさ & 浸潤血管 & Stage & R-number & 萍 切 除 & \\
\hline 1. 56 瓷 & 男 & 嘎胞型 & $\mathrm{Ph}$ & $\mathrm{T}_{2}$ & & II & $\mathbf{R}_{1}$ & Std PD & 健在 (7 年 8 力号) \\
\hline 2. 63筬 & 女*1 & 重胞型 & $\mathrm{Pbh}$ & $\mathrm{T}_{4}$ & $\begin{array}{l}\mathrm{Ach}_{2}, \mathrm{Asp}_{2}, \mathrm{Asm}_{1}, \\
\mathrm{PVp}_{1}, \mathrm{PVsm}\end{array}$ & IV & $\mathbf{R}_{3}$ & $\begin{array}{c}\text { Exd PD } \\
(\mathrm{EW}(+) \text {, 非治港切除 })\end{array}$ & $\begin{array}{l}\text { 直死 } \\
\text { (彷後出血, } 1 \text { 週間) }\end{array}$ \\
\hline 3. 59 煘 & 男 & 重胞型 & $\mathrm{Ph}$ & $\mathrm{T}_{3}$ & & III & $\mathbf{R}_{2}$ & Exd PD & 健在 ( 5 年 5 力月) \\
\hline 4. 73 歳 & 男 & 咅胞型 & Phb & $\mathrm{T}_{3}$ & & III & $\mathbf{R}_{\mathbf{2}}$ & Exd PD & 健在 ( 2 年11力月) \\
\hline 5. 59 瓷 & 男 & 重胞型 & $\mathrm{Pt}$ & $\mathrm{T}_{4}$ & & N & $\mathbf{R}_{\mathbf{1}}$ & Std DP (t) & 健在( 1 年 9 力月) \\
\hline 6. 62歳 & 女 & 胞型 & Phb & $T_{4}$ & $\begin{array}{l}\mathrm{Ach}_{3}, \mathrm{PV}_{3} \\
\mathrm{PVsm}_{3}, \mathrm{PV} \mathrm{sp}_{3}\end{array}$ & $\mathrm{~N}$ & $\mathbf{R}_{\mathbf{3}}$ & Exd TP & 健在 ( 1 年 2 力月) \\
\hline 7. 62 瓷 & 男 & 萑胞型 & $\mathrm{Pbh}$ & $\mathbf{T}_{4}$ & & IV & $\mathbf{R}_{1}$ & $\begin{array}{l}\text { Std DP (subtotal) } \\
\text { +尾㑡愺自家移植 }\end{array}$ & 健在 ( 1 年 2 力月) \\
\hline
\end{tabular}

・1 : 症例 2 は胃・十二指腸・湔の三膈器重裉癌である。

\section{II. 胞型愺淿切除症例（表 2 ）}

7 例がこれに分類され，肉眼的性状はすべて豪胞型 であった，膆頭部癌 4 例，体尾部癌 3 例で，大きさは $\mathrm{T}_{2-4}$ であり，中でも症例 6 は最大经 $11 \mathrm{~cm}$ の巨大な軎 胞状尰㻛であった. Stageは 4 例がIVで 2 例がIII, 1 例 がIIであった，症例 $2 ， 6$ K門脈，上腸間膜動脈，腹 䐁動脈あるいはその幹枝に肉眼的浸潤がみられたが， 前者は血管合併切除せず，後者は門脈之腹腔動脈を合
併切除した. Std PD 2 例, Std DP 1 例, $R_{2}$ Exd PD 2 例, $R_{3} \operatorname{Exd} T P 1$ 例, 以上の 6 例は肉眼的治瘾切除 であった。初期の頃に経験した症例 2 は他誌)に詳細 を報告したが，胃，十二指腸にも多発性癌腫のある三 蔵器重複癌で $R_{3}$ Exd PDを行ったものの，浸潤血管剝 離部が $\mathrm{EW}(+)$ であり，肉眼的非治篗切除であった。 本研究では血管合併切除のために TP となった症例 に尾側脺自家移植を併せ行った症例は PDに含めた。 
私達の行っている血管合併切除子払大膵切除の術 式3)，脺癌における脺 (亚) 全摘時の尾側膵異所性自家 移植の適応とその意義(), 拉よび術式似ついては他誌 に詳述したので割愛した。をた，膵切除は腫湯辺縁よ り最低 $3 \mathrm{~cm}$ は離して膵を切断し, 適宜, 術中迅速病理 診断にて膵切除断端 pw（一）を確認した。

なお, 非切除の17例は腹腔外遠隔他瞊器転移 $\mathrm{M}, \mathrm{H}$, 腹膜播種性転移 P 因子のいずれかが陽性の，あるいは 広籁囲な腸間膜リンバ節転移の見られた症例である。 いずれも生検等で膵管癌であることを確定診断した が, 畽場の肉眼形態は全例とも充実型であった。

以上の切除症例についてそれぞれのタイブ別に光顕 レベルでの組織学的検索を行い, その進展様式につい て検討した。な找，組織型の分類は取扱い規䄪に従っ たが，膵管内乳頭腺癌の主㬵管型と分枝型の分類につ いては黒田らの試案けに従った。本研究では膵内での 浸潤態度として周囲組織への浸潤増殖様式 INF, 静脈 浸潤 v, 膵内神経浸潤 ne, リンパ管浸潤 ly, 主膵管内 進展 $\mathrm{d}$ 因子を，膵後方および前方への漫潤は rp, s 因 子を, 勝外への浸潤進展態度として膵外神経凿浸潤 $\mathrm{plx}$, リンパ節転移 $\mathrm{n}, \mathrm{a}, \mathrm{pv}$ 因子を, 切除断端（勝， 胆管）扰よび剩離面の浸潤 pw，bdw，ew 因子を検討 した。これらは腫湯の占居部位にかかわらず険討した ので本研究では膵内胆管および十二指腸壁への浸濶 ch，duについては特には取り上げなかった。また，a， pv因子については合併切除した腹腔動脈およびその 幹枝, 上腸間膜動脈, 上腸間膜静脈根部を含む門脈な どの血管を中心に検討した。 なお，取扱い規約によ れば充実型膡癌症例13の腫瘍占居部位 $\mathrm{Pbh}$ は体尾部 癌になるが、リンパ節郭清についての同規約の記載で は頭部と体部にまたがる場合は各症例で考虑すること になって怙り，腫煌は明らかに体部から頭部に抾が ていたので本研究ではリンバ節郭清については本症例 を脺頭部癌として扱った。

以上の 23 例中の死亡 13 例のうち, 8 例に剖検を行い, 再発転移について検討した。

累積生存率は Kaplan-Meier 法を用いた。

\section{結果}

\section{I. 充実型滕癌切除症例組織学的所見（表 3)}

i）組織型：乳頭管状一管状腺癌であり,分化度は高 分化型 6 例, 中分化型 6 例, 低分化型 4 例と注添均等 に存在した。

ii）膵内での浸潤：INFは $\alpha 1$ 例（症例10）の及で, 他は $\beta 7$ 例, $\gamma 8$ 例之罍が周围儿向って浸潤性増殖を 示すむのが多かった. 静脈浸潤は全症例でみられ、 $\mathbf{v}_{1} 1$ 例, $v_{2} 5$ 例， $v_{3}$ 10例上大部分は強い静脈漫潤を示した。 膵内神経浸潤およびリンバ管浸潤は全症例でみられ， しかも 1 例(症例11)のみが $\mathrm{ne}_{2}, \mathrm{ly}_{2}$ で他はすべて $\mathrm{ne}_{3}$,

表 3 充実型膡癌切除症例組織学的所見

\begin{tabular}{|c|c|c|c|c|c|c|c|c|c|c|c|c|c|}
\hline 症例 & 組皒学的分類 & INF & $\mathrm{v}$ & ne & ly & $d$ & rp & $\mathbf{s}$ & plx & ew & $n^{* 1}$ & $\mathbf{a}$ & ${ }^{* 2} \mathrm{pv}$ \\
\hline 1. & 高分化型管状腺癌 & $r$ & 2 & 3 & 3 & $(-)$ & e & o & $(-)$ & $(+)$ & $\mathrm{n}_{1}(+)$ & & \\
\hline 2. & 中分化型乳頭管状腺淘 & $\beta$ & 3 & 3 & 3 & $(+)$ & o & 0 & $\Leftrightarrow$ & $(-)$ & $\mathrm{n}_{1}(+)$ & & 0 \\
\hline 3. & 高分化型管状腺癌 & $\beta$ & 2 & 3 & 3 & $(+)$ & e & e & $(t)$ & $(-)$ & $n_{1}(+)$ & 0 & \\
\hline 4. & 中分化型乳頭管状腺癌 & $r$ & 3 & 3 & 3 & $(+)$ & $\mathrm{e}$ & $\mathrm{e}$ & $(+)$ & $(-)$ & $\mathrm{n}_{1}(+)$ & $?$ & 2 \\
\hline 5 . & 高分化型管状腺癌 & $\beta$ & 1 & 3 & 3 & (b) & e & o & $(-)$ & $(-)$ & $\mathrm{n}_{1}(+)$ & 1 & 1 \\
\hline 6. & 高分化型管状腺癌 & $r$ & 3 & 3 & 3 & (b) & $\mathrm{i}$ & $\mathrm{i}$ & $(+)$ & $(t)$ & $\mathrm{n}(-)$ & 1 & 2 \\
\hline 7. & 低分化型乳頭管状腺渵 & $\beta$ & 3 & 3 & 3 & $(+)$ & $\mathrm{e}$ & $\mathrm{i}$ & $?$ & $(-)$ & $\mathrm{n}_{1}(+)$ & & \\
\hline 8. & 中分化型管状腺癌 & $r$ & 2 & 3 & 3 & $\Leftrightarrow$ & e & 0 & $(+)$ & $(-)$ & $\mathbf{n}_{1}(+)$ & 1 & 1 \\
\hline 9. & 低分化型管状腺癌 & $r$ & 3 & 3 & 3 & $(t)$ & $\mathrm{i}$ & 0 & $?$ & $(+)$ & $\mathrm{n}_{1}(+)$ & 1 & 2 \\
\hline 10. & 低分化型管状腺癌 & $a$ & 2 & 3 & 3 & $(-)$ & o & e & $?$ & $(-)$ & $\mathrm{n}_{2}(+)$ & & \\
\hline 11. & 高分化型管状腺癌 & $\beta$ & 3 & 2 & 2 & $(+)$ & e & o & $(t)$ & $(-)$ & $\mathbf{n}_{1}(+)$ & & 0 \\
\hline 12. & 中分化型管状腺癌 & $r$ & 3 & 3 & 3 & $(-)$ & $\mathrm{e}$ & o & $(+)$ & $(t)$ & $\mathrm{n}_{1}(+)$ & & 0 \\
\hline 13. & 中分化型乳頭管状腺㿋 & $\beta$ & 3 & 3 & 3 & $(-)$ & e & $\mathrm{i}$ & $(+)$ & $(+)$ & $\mathrm{n}_{3}(+)$ & 1 & 2 \\
\hline 14. & 低分化型管状腺癌 & $r$ & 2 & 3 & 3 & $(-)$ & $\mathrm{i}$ & 0 & $(+)$ & $(+)$ & $\mathrm{n}_{1}(+)$ & 1 & 2 \\
\hline 15. & 中分化型管状腺癌 & $\beta$ & 3 & 3 & 3 & $(-)$ & $\mathrm{e}$ & $\mathrm{e}$ & $(-)$ & $(+)$ & $\mathrm{n}_{1}(+)$ & & 2 \\
\hline 16. & 高分化型乳頭管状腺癌 & $r$ & 3 & 3 & 3 & $(+)$ & $\mathrm{i}$ & $\mathbf{i}$ & $(+)$ & $(+)$ & $\mathrm{n}_{1}(+)$ & & $\begin{array}{c}2 \\
\left(\mathrm{icv}_{2}\right)^{* 3}\end{array}$ \\
\hline
\end{tabular}

・1：nに付記した数字は第何群リンパ節まで転移が認められたかを示す。

*2：a,pv は合併切除血管壁への最大浸潤を示す。

$* 3: \mathrm{icv}_{2}=\mathrm{ICV}$ への intimal invasion 


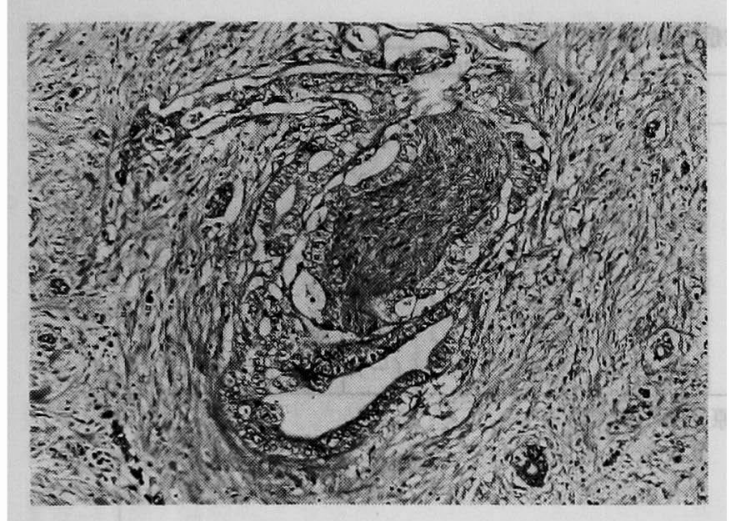

図 1 充実型膵癌（症例12）切除腈の組織学的所見： perineural invasionを主とする著明な膵内神経浸 潤 $\left(\mathrm{ne}_{3}\right)$ とリンパ管浸潤 $\left(\mathrm{ly}_{3}\right)$ が見られる（HE 染 色, $\times 17)$.

ly 3 であった. なお, 神経浸潤はいわゆる perineural space への浸潤が主で一部は神経線維束にも癌細胞の 侵入を認めた。 これらの脺内神経およびリンパ管浸潤 はどの症例においても畽瘍中心部に限らず腫瘍辺縁部 でも明瞭に観察された(図 1). 主膵管内進展は 7 例で $\mathrm{d}(+), 2$ 例で $\mathrm{d}(\mathrm{b}), 7$ 例で $\mathrm{d}(-)$ であったが， d $(+)$ 例のものはいずれも腫崵内でみられ, 膵管内非連 続性進展はどの症例ですみられなかった，以上の膵内 での浸潤態度は組織型の分化度にかかわらず強い浸潤 型を示した。

iii）膵後方, 前方浸潤：前方浸潤は so 8 例, se 4 例, si 4 例に対し, rpoは 2 例のみで, rpe 10例, rpi 4 例と後方への浸潤は極めて高度に認められた。

iv）膵外一の浸潤進展：plx (+)は9例にみられ， これらはすへて rpe または rpi の症例であった。郭清 リンパ節の転移は16例中15例にみられ，第 1 群リンパ 節まで転移のあった $\mathrm{n}_{1}(+) 13$ 例，第 2 群までみられ た $\mathrm{n}_{2}(+) 1$ 例，同様に $\mathrm{n}_{3}(+) 1$ 例であった。転移 リンパ節は苏頭部癌11例では第 1 群リンパ節の $13 \mathrm{a}$ ( 6 例，55\%)，14a (45\%)，14V (45\%)，13b (36\%)， $8 \mathrm{a}(18 \%), 12 \mathrm{~b}_{2}(18 \%), 14 \mathrm{~b}(18 \%), 8 \mathrm{p}(9 \%), 12$ $\mathrm{p}_{2}(9 \%), 14 \mathrm{~d}(9 \%), 17 \mathrm{a}(9 \%), 17 \mathrm{~b}(9 \%) k$ 認められ，第 2 群リンパ節の $16(9 \%)$, 第 3 群リンパ 節の 4（9\%）に認められた．体尾部癌 4 例では第 1 群リンパ節の10 ( 3 例，75\%)，18(50\%)，8p(25\%), 9 (25\%)，14a (25\%)，14d (25\%)，第 2 群リンパ節 の16（25\%）に認められた，大血管浸潤では $\mathrm{PV}_{2}$ 以上 の漫潤で門脈を合併切除した12例のうち， $\mathrm{pv}_{1}$ 以上(図
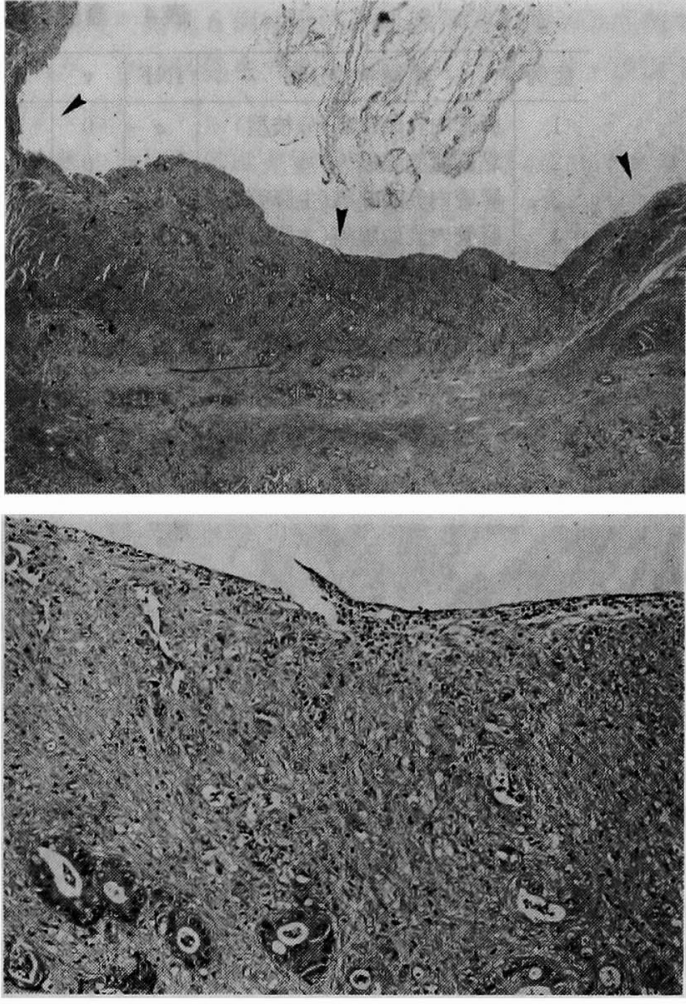

図 2 充実型膵癌（症例16）の門脈壁への漫潤：浸潤 は主として中膜であるが，一部内膜にも認められる $\left(\mathrm{pvp}_{2}\right)$.

(上段：矢じりは門脈内腔を示す. $\mathrm{HE}$ 染色, $\times 3.3$, 下段：同扗大像, $\times 33$ )

2 )は 9 例で $\mathrm{pv}_{0}$ は 3 例であった. $\mathrm{A}_{2}$ 以上で動脈を合併 切除した 8 例中, $a_{1}$ が 6 例， $a_{0}$ が 1 例，a (不明) かi 1 例であった。

v）切除断端および剥離面における浸潤：全例とも pw (-), bdw（一)であったが, ew は 8 例で（十）

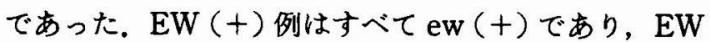
(一)であっても6例は ew (十)であった。 以上から

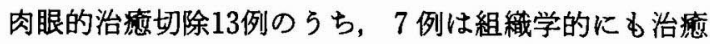
切除であったが, 他の 6 例は ew (十)のために組織学 的に非治瘁切除となった。

\section{II. 型胞萃癌切除症例組織学的所見 (表 4)}

i) 組織型：膵管内乳頭腺癌 3 例（主膵管型 2 例, 分 枝型 1 例, 図 3 ), 粘液襄胞腺癌 3 例, 粘液癌 1 例であっ た.

ii）膵内での浸潤：粘液癌の症例 6 のみが INF $\beta$ で 他はすべて INF $\alpha$ であった。静脈浸潤も症例 6 のみが $\mathrm{v}_{2}$ で, 他は全例 $\mathrm{v}_{0}$ であった。膵内神経浸潤は全例 $\mathrm{ne}_{0}$ で 


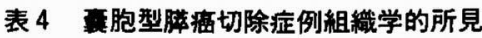

\begin{tabular}{|c|c|c|c|c|c|c|c|c|c|c|c|c|c|}
\hline 症例 & 組織学的分類 & INF & $\mathrm{v}$ & ne & ly & d & $\mathrm{rp}$ & s & plx & ew & $\mathrm{n}$ & a & ${ }^{* 2 \mathrm{pv}}$ \\
\hline 1. & 苏管内乳頭腺癌 (分枝型) & $\alpha$ & 0 & 0 & 0 & $(-)$ & 0 & 0 & $(-)$ & $(-)$ & $\mathrm{n}(-)$ & & \\
\hline 2. & 粘液要胞腺癌 & $\alpha$ & 0 & 0 & 0 & $(-)$ & 0 & 0 & $(-)$ & $(+)$ & & & \\
\hline 3. & 羘管内乳頭腺癌 (主脺管型) & $a$ & 0 & 0 & 0 & $(+)$ & 0 & o & $(-)$ & $(-)$ & $\mathrm{n}(-)$ & & \\
\hline 4. & 腪管内乳頭腺癌 (主羘管型) & $\alpha$ & 0 & 0 & 0 & $(+)$ & 0 & 0 & $(-)$ & $(-)$ & $n(-)$ & & \\
\hline 5. & 粘液垂胞腺癌 & $\alpha$ & 0 & 0 & 0 & $(-)$ & o & 0 & $(-)$ & $(-)$ & $\mathrm{n}(-)$ & & \\
\hline 6. & 粘液癌 & $\beta$ & 2 & 0 & 1 & $(+)$ & e & $\mathrm{i}$ & $(-)$ & $(-)$ & $\mathrm{n}(-)$ & 0 & 1 \\
\hline 7. & 粘液賈胞腺癌 & $\alpha$ & 0 & 0 & 0 & $(+)$ & 0 & 0 & $(-)$ & $(-)$ & $\mathrm{n}(-)$ & & \\
\hline
\end{tabular}

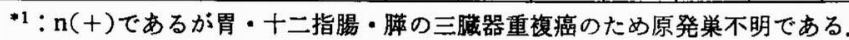

•2 : a,pv は合併切除血管壁への浸潤を示寸。

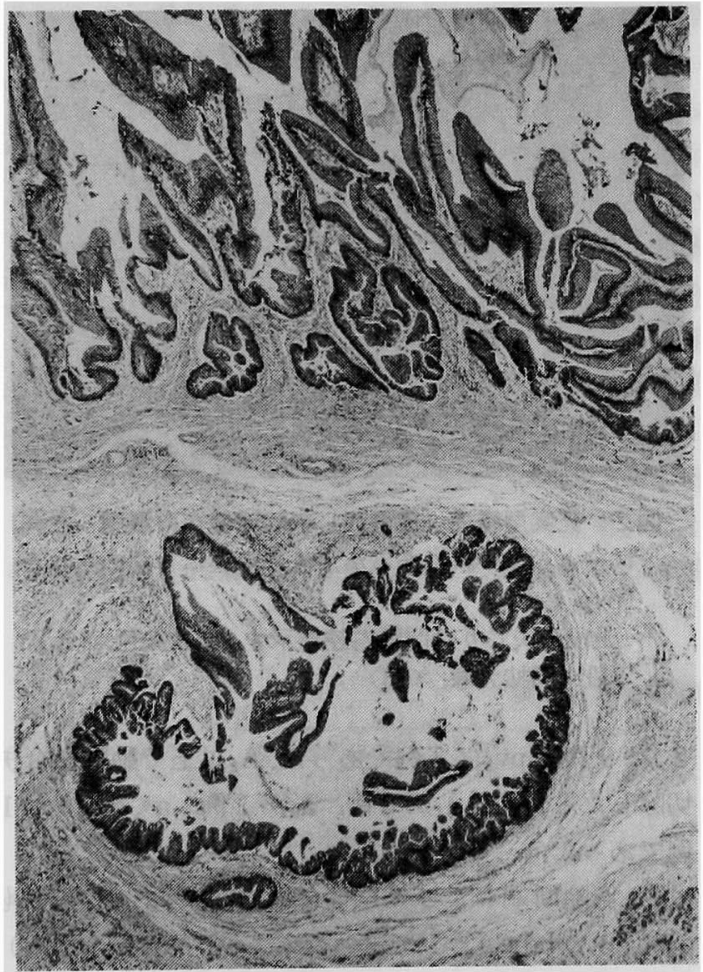

图 3 型胞癌（症例 4）切除墙の組織学的所見： 主膵管型の膆管内乳頭腺癌であるが，写真上部の主 膵管内の腫場は写真下部の第 2 次膵管に連続性に進 展している，腫場は脺管内にとどまっており，周囲 への浸潤は見られない $($ HE 染色, $\times 20)$.

あったが、リンバ管漫潤は症例 6 のみが $\mathrm{ly}_{1}$ で，他はす

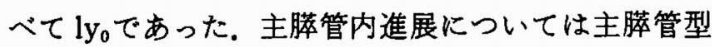
膵管内乳頭腺癌の 2 例と， $T_{4}$ で主膵管を involve した 粘液癌と衰胞腺癌の各 1 例, の 4 例が腫瘍の範囲内で $\mathrm{d}(+)$ であったが，膵管内を腫瘍を越えて拡がるるの や非連続性に進展するすのはなかった。

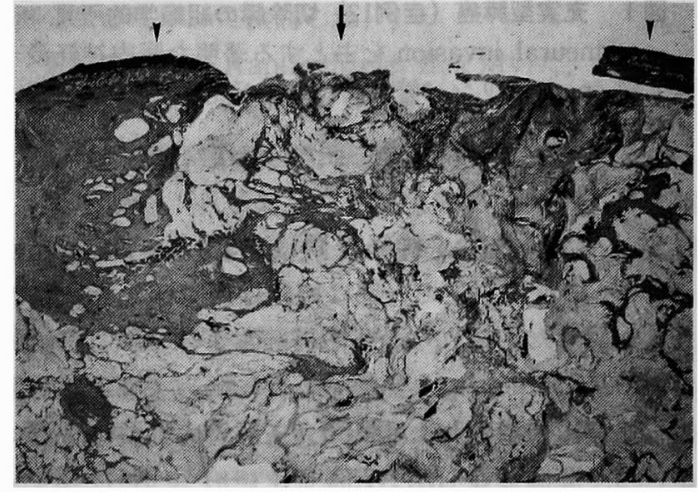

図 4 萧胞型膆癌（粘液癌，症例 6）の十二指腸壁へ の漫潤：十二指腸粘膜層に浸潤し，潰瘍形成が認め られる $\left(\mathrm{du}_{3}\right)$.

（矢じりは十二指腸粘膜，矢印は潰瘍形成部を示す. $\mathrm{HE}$ 染色, $\times 5$ )

iii）膵後方，前方浸潤：症例 6 を除いて，全例 rpo, soであった. 上述の膵内でやや浸潤型を示した粘液癌 の症例 6 は rpe, si（胃）と，ここでも浸潤型を示し， 十二指腸粘膜層にも漫潤して潰瘍形成が認められた ( $\left(\mathrm{du}_{3}\right.$, 図 4 ).

iv）膵外への漫潤進展：全例が plx（一）であった。 特に rpe の症例 6 す plx (一)であった，郭清リンバ節 の転移は胃, 十二指腸との三藏器重複癌の症例 2 は 6 , $10,8 \mathrm{p}, 12 \mathrm{p}_{2}, 16$ 番リンバ節に転移があったが原発巣 が不明なのでこれを除くと，全例 $\mathrm{n}($ (一)であった，血 管合併炀除した症例 6 では $\mathrm{Ach}_{3}$ にすかかわらず $\mathrm{a}_{0}$ で あり, $\mathrm{PV}_{3}$ は $\mathrm{pv}_{1}$ であった。

v）切除断端扣よび剝離面に拁ける浸潤：全例とも pw (一), bdw (-) であった. EW (十)であった症 例 2 を除いて全例 ew (一)であった，以上から症例 2 を除いて全例が肉眼的にも組織学的にも治福切除で あった。 


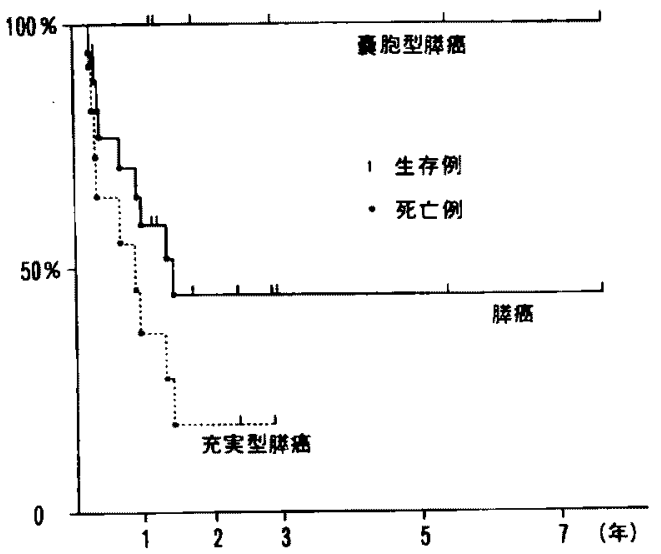

图 5 内眼的治病切除症例の果积生存率

\section{III. 切除拏およU゙手術直接死亡例}

膟管癌全例の手術切除率は23/40（58\%）であるが, 充実型のそれは16/16+17（48\%）となり，䔶胞型は 100\%の切除率である. 手術直接死亡は充実型, 画胞型 各々1例にみられた。

\section{IV，遠隔成繢（図 5，表 1〜4）}

切除症例の耐術例における肉眼的治痹切除症例の累 積生存率は脺管癌全体では 1 年生存率 $60 \%, 2$ 年以後 7 年まで $44 \%$ を得た。これを充実型，恶胞型のタイプ 別にみると，前者の 2 年生存率 $18 \%$ (同 1 年37\%) に 対し，後者は 7 年生存率 $100 \%$ で 7 カ月以後有意に良好 であった。充実型の 5 ち， 1 年以上生存例は症例 3 , $5 ， 7 ， 8 の 4$ 例であるが，いずれい組織学的治瘜切 除症例である. 逆に,この 4 例に症例 2，4，11を加 えた組織学的治撚切除症例 7 例の5ち，他病死した症 例 4，11を除けば， 5 例中 4 例が 1 年以上生存例であ 万.一方, 組織学的非治窄切除症例 9 例は術後早期生 存中の 2 例は別として全例 1 年以内に死亡した（他病 死 1 例，他はすへて癌死).

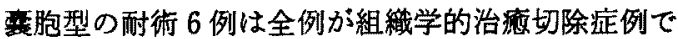
あるが，全症例健在である（最長 7 年 8 カ月〜最短 1 年 2 力月).

耐術の他病死例は充実型に 2 例（症例 4，6）あり， いずれる膵全摘後に脂肪肝を発症して肝不全または心 不全死した，なお，症例 6 は後述の剖検にて肝転移と 局所発発が認められたが，脂肪肝が著明であり，肝不 全死とした。

\section{V. 剖検所見（表 5)}

8 例の剖検症例の5ち, 耐術の剖検 6 症例すべてが 充実型であり，程度の差はあるbのの全例に肝転移と 後腹膜局所再発が見られた，肝転移例の手術時組織学 的所見は全例が $\mathrm{v}_{2-3}$ であり, 門脈切除 5 症例中， 3 例 が $\mathrm{pv}_{2}$ で 1 例が $\mathrm{pv}_{1} ， 1$ 例は $\mathrm{pv}_{0}$ であった。同様に動脈 切除 5 例中， 4 例が $a_{1}$ で 1 例は $a_{0}$ であった。後腹膜再 発例は全例が rpe むしくはrpi であったが, ew は 4 例 が(十)で 2 例は（一)であった，PDやDPにおける 残脺再発は 1 例（充実型症例12）に見られた。これは 他誌"゙に詳細を報告したが、主膵管が尰瘍に involveさ れ末梢主膵管が拡張した膵頭部癌の PD（尾側膵異所 性自家移植) 症例であり，残膵の勝断端あるいは主膵 管とは離れた部位に小さいskip lesionの遗残による と思われる再発が見られた（図6）。

その他の葴器で多数転移が見られたことは当然とし てもTPと DP (subtotal) また，1力月，1週間で死亡した手術直接死亡例はそ れぞれ，心能梗塞，浸潤血管剩離部の仮性動脈瘤破裂 による出血死によるすのであった。

$$
\text { 考察 }
$$

悪性疾患に対する手術術式の選択は通常, 術前, 術 中に得た情報をるとにその進展様式を判断して決定さ れる、膵癌における手術成績が悪い原因のひとつはそ の䙓雑な進展様式にある。一方, 膵（亜）全摘後の膵

表 5 剖検所見

\begin{tabular}{|c|c|c|c|c|c|c|}
\hline 症 & 例 & 生存期間 & 肝転移 & 後腹膜再発 & 残胼再発 & の \\
\hline 充夷型羘湻注例 & $3(\mathrm{DP})$ & 1 年 4 力月 & 有 & 著明 & 無 & 癌性腹膜炎 \\
\hline 充実型䐙癌症例 & $8(\mathrm{PD})^{*}$ & 1 年 5 カ月 & 著明 & 著明 & 無 & \\
\hline 充実型腪癌症例 & $12(\mathrm{PD})^{*}$ & 11カ月 & 有 & 著明 & 有 & 肺，骨転移 \\
\hline 充実型䐙癌症例 & $13(\mathrm{TP})$ & 4 カ月 & 有 & 著明 & & 全身諸䁍器転移 \\
\hline 充実型臉癌症例 & $14(\mathrm{DP})$ & 8 力月 & 有 & 著明 & 無 & 滛性腹膜炎, 脂肪肝 \\
\hline 充実型苹癌症例 & $6(\mathrm{TP})$ & 4 力月 & 有 & 有 & & 脂肪肝 \\
\hline 充奏型䐙癌症例 & $11(\mathrm{PD})^{* *}$ & 1 力月 & 無 & 無 & 無 & 心能梗塞 \\
\hline 璪胞型椫癌症例 & $2(\mathrm{PD})^{* *}$ & 1週間 & 無 & 無 & 無 & 脾動脈仮性動脈疾破裂 \\
\hline
\end{tabular}

"TP 後尾側苹異所性自家移植淀例 **手泪直接死亡例 


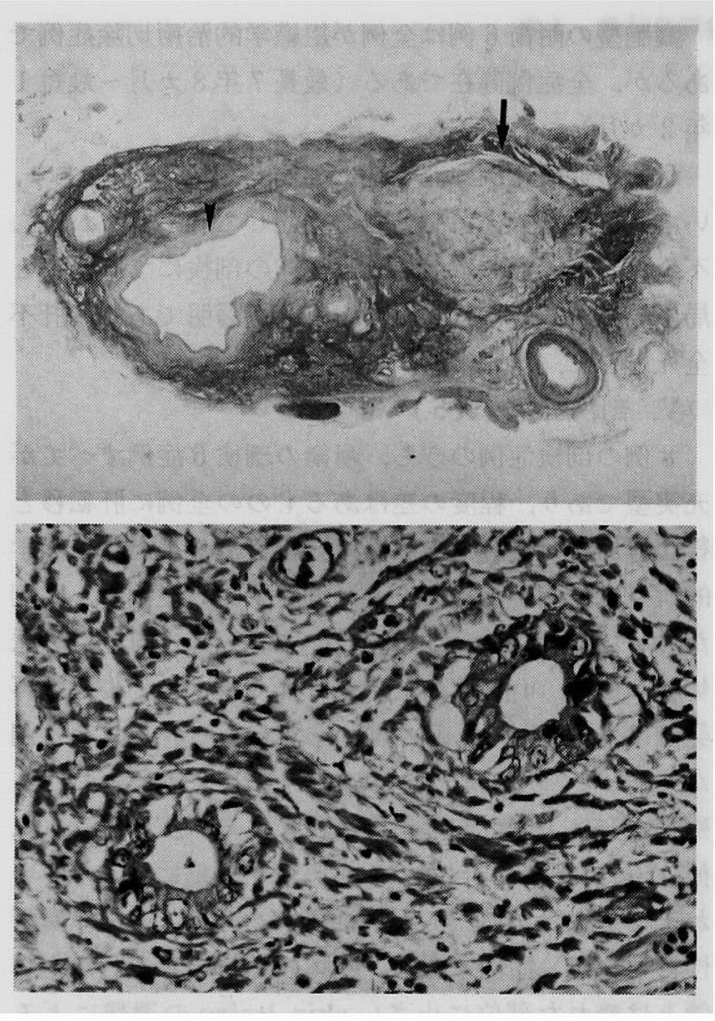

図 6 充実型膵癌 PD 症例（症例12）における残膵再 発：膵断端あるいは主膵管とは離れた位置に skip lesionの遺残によると思われる小再発单が見られ る.再発巣は原発巣と同じ中分化型管状腺癌である. （上段：矢印は再発巣，矢じりは主脺管を示す， $\mathrm{HE}$ 染色, $\times 2$, 下段：再発巣扗大像, $\times 200$ )

機能欠落症状は厳しく，また，解剖学的関係から膵癌 は門脈, 腹腔動脈とその幹枝, 上腸間膜動脈などの大 血管を巻き込むことも多く，これに対する血管合併切

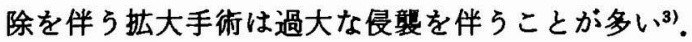
従って, 膡癌においてはその進展様式を術前, 術中に 得た所見をもとにできるだけ正確に把握して適切な手 術術式を選択する必要がある。

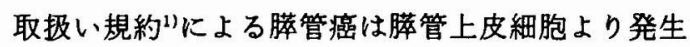
する膵癌とされ，これには従来より浸潤型といわれる 乳頭腺癌や管状腺癌のいわゆる通常型膵癌のほか, 比 較的予後が良いといわれる襄胞膵癌や最近報告の増加 している粘液産生癌的すすべて含まれており，乙かも 組織学的分類では重なり合う部分すある。私達はこの 膵管癌を肉眼形態からと充実型と襄胞型に大別した。 ここで，取扱い規約の肉眼分類では中心壊死によって 董胞状になったものは衰胞型とされているが，今回の
症例ではもともと充実型と思われる膵癌が大さく壊死 に陷って裹胞状になったすのはなかった。一部が壊死 に陷っている症例はあったが，これは術前の画像診断 や術中所見で容易に判断でき，しか子腫瘍の本来の性 格が変わるわけではないので本研究では充実型とし た。 その結果, 膵管癌切除23例中, 16例が充実型, 7 例が裏胞型に分類された。組織型から見ると前者は高 分化から低分化にまたがった乳頭管状一管状腺癌で， いわゆる通常の浸潤型膵癌に含まれるものである，後 者は膵管内乳頭腺癌, 粘液譱胞腺癌, 粘液癌であり,

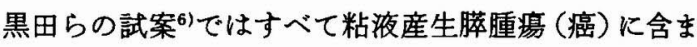
れるすのである。

本研究ではいわゆる小膵癌8は皆無で，すべてが $\mathrm{T}_{2}$ 以上の進行した膵癌であったが，これらの進展様式に ついて手術術式に関連して考察する。

膵切除範囲を決定する主要因は膵内での連続性進展 であるが，充実型は多くの報告9)10) と同様に腫湯は周 囲に向って浸潤性増殖を示すすのが多く，全例に著明 な膵内神経浸潤およびリンパ管浸潤が見られた，今回 の症例ではこれらの浸潤態度と組織分化度の間に相 関101は見られなかった。これらの神経およびリンバ管 浸潤は董瘍辺緑部でも著明に観察され，癌浸潤の先進 部になっている可能性があり, 膵癌の連続性進展の最 大要因と考えられた，私達は適宜，術中迅速病理診断 を用いながら，睡煬辺縁から少なくとも $3 \mathrm{~cm}$ は離して 膵を切断したが，断端の組織学的浸潤はすべて陰性で あった。この $3 \mathrm{~cm}$ といら数字は諸家 ${ }^{1112)}$ の報告か2 24 $\mathrm{cm}$ であり，ほぼ同様の数值である.この点から今回の 症例を見返すと, TP 5 例中, 初期の 1 例（症例 2 )は $\mathrm{PD}$ の適応でよかったと思われ，更に，膵全摘後 2 例と 亜全摘後 1 例に脂肪肝が見られたことからも膵切除範 囲は可能なかぎり縮小すべきであると反省している。 一方, 震胞型のはとんどは上述のような浸潤性はなく, 腫場周囲に対しても非漫潤性で尰場辺縁も明確なこと が多かった. 私達はこれらにも $3 \mathrm{~cm}$ は離して膵切断し たが，その必要はなく確実に董愓が切除されればすっ と接近して切断してるよいのではないかと考えてい る.しかし，黒田ら ${ }^{6}$ す述べているよ5に粘液産生癌の らちでも進行した粘液癌は, 私達の症例でも同様で あったが，漫潤型の性格を帯びてくるのでこの点では 浸潤型としての扱いが必要であろう。

膵切除範囲に関してもらひとつの問題に腫瘍の非連 続進展や多中心性発生がある. 本研究の切除脺には膵 管内非連続性進展や多中心性脺癌は見られなかった 
が，充実型の PD の 1 例に剖検にて残膵の膵管とは離 れた位置に skip lesionの遗残によると思われる小再 発巣が見られた，本症例の残膵は異所性自家移植萃で あり外 (局所再発)からの侵入は否定できる. Nakase ら 続性進展が生じ得ることを実験的に証明しており，本 症例も主膵管閉塞のため随伴性萃炎（膵液らっ渟）を 伴っている高度リンパ管浸潤例であり，これによる skip lesion と考えて矛盾はない，頻度はそら高くない にしろ，特に随伴性膵炎を伴っている充実型䐺癌の症 例では尾側への skip lesionの存在を考える必要があ る.

膵癌手術において根治性を得る最大ポイントは後方 郭清である．充実型膵癌における脺後方への浸潤は高

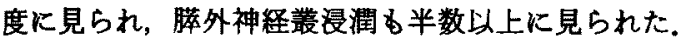
菅原ら 潤する可能性が高いと報告しているが，私達の症例の

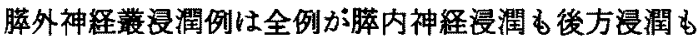
共に高度であり，膵外神経叢に外から侵入したのか膵 内神経上り連続性に浸潤したのか，本研究では連続切 片を作製していないので不明である．私達は腈外神経 叢はもらろん血管合併切除を含む相当深い後方郭清を 行ったが，それでる半数はew（十）であり，しかる， これらの大部分は $\mathrm{EW}(ー)$ であった。これが肉眼的 治㴼切除を多数, 組織学的非治撚切除にした最大の要 因である。植松らりる同様の報告をしているが，後方郭 清の困難さはここにあると思われる。これに対し，衰 胞型は後方浸潤が問題となる症例はなかった，巨大で やや浸潤型となった粘液癌の 1 例は門脈と肝動脈合併 切除を要し，rpeであったが，それでも plx (一), ew (ー)であった.

膵癌のリンパ節転移は諸家 ${ }^{1115)}$ の報告ですきわめて 高率であるが，本研究の充実型では16例中15例(94\%) に見られ，そのちち13例は第 1 群リンパ節のみであっ た。第 2 群リンバ節で転移陽性であったのは16番のみ であった。一方，蔃胞型では三葴器重複癌の 1 例を除 いて全例にリンパ節転移は見られなかった，従って， リンバ節郭清は充実型膵癌では $\mathrm{R}_{2}$, 萎胞型脺癌では $\mathrm{R}_{1}$ が至当と思われ，症例によっては前者は $\mathrm{R}_{1}+16$ 番 リンパ節, 後者は $\mathrm{R}_{0}$ の郭清でるよいのではないかと思 われた。この点で今回の症例は過大なリンパ節郭清を したのもあり，今後の問題であると思っている.

門脈，腹腔動脈およびその幹枝，上腸間膜動脈など の大血管に浸潤した膵癌す多かった。肉眼的浸潤のた
めこれらの大血管を合併切除した症例は充実型13例， 琵胞型 1 例の14例（切除23例中61\%）で，この5ち門 脈切除は13例 (56\%)，動脈切除は 9 例 (39\%) であっ た. 全国膵癌登録調査報告（日本膵㵴学会膵癌登録委 員会, 1988年度：以下, 全国調査報告) ${ }^{16}$ の膵切除397症 例中，門脈切除84例 (21\%)，動脈切除21例（5\%）か らみると私達の血管合併切除症例は多い，私達は $\mathrm{PV}_{2}$ 以上， $\mathrm{A}_{2}$ 以上の血管を切除したが，切除血管の組織学 的浸潤は $\mathrm{pv}_{1}$ 以上が10例， $\mathrm{pv}_{0} か 33$ 例， $\mathrm{a}_{1}$ が 6 例， $\mathrm{a}_{0}$ が 2 例， $\mathrm{a}$ (不明)が 1 例であった. $\mathrm{PV}_{2}$ 以上と $\mathrm{pv}_{1}$ 以上, あるいは $\mathrm{A}_{2}$ 以上と $\mathrm{a}_{1}$ 以上の間の不一致は全国調查報 告の切除例です $\mathrm{PV}_{2}$ 以上 125 例に対し $\mathrm{pv}_{1}$ 以上 80 例, 同 様に動脈は91例対28例と大きく，むしろ私達の症例の 方が小さかった。これらの血管の組織学的浸潤は当然, 漫潤型である充実型膵癌に多かったが，䒼胞型です粘 液癌など相当進行したものでは見られた，血管合併切 除は膵切除範团の搪大や他蔵器合併切除につながるの で3)，可能なかぎり避けたいが，今回の 1 例でも見られ たよらに浸潤血管の無理な剥離は仮性動脈瘤を生じて 大出血をきたすこともある．以上から血管合併切除は 術前の血管造影所見中術中に得た肉眼所見が実際の組 織学的浸潤と必ずしも一致しないことを念頭において 慎重に行ら必要がある。

さて，手術成績を全国調査報告と対比しながら考察 すると，手術切除率は全国的には約 $50 \%$ であるが，今 回の研究では58\%であった，これを充実型，要胞型の タイブ別にみると前者は $48 \%$, 後者は $100 \%$ と正倒的な 差がみられた。手術直接死亡は本研究では 2 例であっ たが，これは全国成績と差はない，1988年をでの全国 登録症例切除例の累積生存率は 1 年 $50 \%, 5$ 年 $17 \%$, 8 年15\%である. 本研究の遠隔成續は肉眼的治瘦切除 症例のものであるが， 1 年 $60 \% ， 5$ 年 $44 \% ， 7$ 年 $44 \%$ であった。しかし，これは霋胞型の症例が 7 年生存率 100\%であるために引き出された数字で, 充実型に限る と 1 年 $37 \% ， 2$ 年 $18 \%$ であり，票胞型に比べると王倒 的に悪かった。この差は, 剖検所見からみても癌死例 は全例に肝転移と後腹膜局所再発が見られ，充実型で はこれに直結する $\mathrm{v}$ 因子と $\mathrm{rp}$ 因子が極めて激しく， 逆に震胞型ではこれらの因子が極めて低いことが最大 の原因（䂆後規定因子）と考党られる．更に，これに は pv 因子やa因于す関保していると思われるが，こ の点については症例を重机てから分析するつもりであ ク，今回は差し控えたい，さて，充実型脺癌では 1 年 以上生存例はすべて組織学的治癒切除症例で, 逆に組 
織学的非治痗切除症例は 1 年以内に死亡した。前述し たように肉眼的治䈍切除が組織学的非治癁切除となっ た症例の最大要因は ew (十)であり，これが手術時に 肉眼的治疾切除と思われた症例における予後規定因子 になっていると考えられる。

以上，同じ膵管癌であっても乳頭管状一管状腺癌で ある充実型膵癌之膵管内乳頭腺癌, 粘液表胞腺癌, 粘 液癌などの莀胞型膵癌ではその組織学的進展様式や予 後の点からみて全く異なると思われ，それに合わせた 妥当な手術術式の選択が必要であろう。

$$
\text { 結語 }
$$

膵管癌切除症例を腫場の肉眼形態から充実型と無胞 型に大別し，その組織学的進展様式から retrospective にみた妥当な手術術式の選択や予後規定因子について 検討した。

(1) 充実型の組織型は乳頭管状一管状腺癌であり，俆 胞型は膆管内乳頭腺癌, 粘液雴胞腺癌, 粘液癌であ。 た.

(2) 充実型は膵内で著明な神経浸潤とリンバ管浸潤 を伴う浸潤性増殂を示したが，腫場辺縁から $3 \mathrm{~cm}$ 離し て切断すれば，脺断端の浸潤は陰性であった。一方， 震胞型は概して漫潤性增殖は見られなかった。

(3) 猝液うっ滞のある充実型膵癌では尾側に skip lesion の存在する危険性がある。

(4) 充実型では後方浸潤が著しく,膵外神経叢を含め て後方郭清を十分に行う必要があるが，臹胞型は後方 への浸潤は少ない。

(5) リンバ節転移は充実型では高率に認められるが, 咅胞型には見られなかった。そ転移リンバ節の分布 からは前者は $\mathrm{R}_{2}$ ，後者は $\mathrm{R}_{1}$ の郭清が至当と考えられ る.

(6) 門脈, 上晹間膜動脈，腹腔動脈とその幹枝への漫 潤は肉眼的所見々組織学的漫潤度が必ずしも一致しな いのでその合併切除は慎重に判断すべきである。

(7) 切除症例の遠隔成績は㯎胞型は極めて良いが充 実型は不良であった。この差を决定している最大の因 子はv因子とrp因子と思われる。また，肉眼的に治垵 切除と思われた充実型膵癌症例の予後規定因子は ew 因子であると考えられる。

稿を終えるにあたり，病理組織学上の御指導を賜った当 大学中央検查部蹦床病理部門の長岡三郎講師，並河 徹先
生，三浦弘資先生に深謝いたします。

$$
\text { 文嗝 }
$$

1）日本膵泟学会編：膵癌取扱い規約，金原出版，東 京, 1986

2）矢野誠司，田村勝洋，安藤静一郎他：同時性三重複 癌（变震胞腺癌・胃癌・十二指晹癌）の 1 切除例， 日消外会誌 $20: 1809-1812,1987$

3）田村勝洋，金 㹂根，小野恵司他：膵癌切除症例の 検討，特に大血管浸㶄膵癌について，日外会誌 $90: 1032-1042,1989$

4）田村勝洋, 中瀬 明：腈自家移植の適応とその意 義, 肝胆脺 $20: 953-960,1990$

5）田村勝洋，中瀬 明：血管吻合に上る膵自家移植 㭪, 外科診療 $27: 1701-1705,1985$

6）黑田慧：最近注目されている櫒腫掦，胆と勝 $9: 1459-1472,1988$

7）田村勝洋, 中川正久, 金 根他：払大滕全摘兼異 所性尾側腈自家移植を行った膵癌 2 症例の移植滕

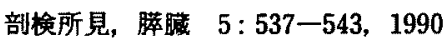

8）中野 哲, 黒田 慧: 小脺癌診断の現況, 胆と膆 $9: 133-139,1988$

9）植松繁人，尾形佳郎：膵癌の切除後生存率を決め る諸因子一神経浸潤，日臨 $44: 1766-1769,1986$

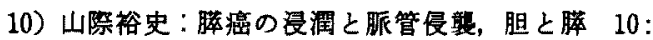
803-806, 1989

11）石川 治, 大東弘明，今岡真義他：膵顽部癌に対す る膵切除範囲についての跻床病理学的検討, 日外 会誌 $85: 363-369,1984$

12) Fortner JG: Regional pancreatectomy for cancer of the pancreas, ampulla and other related sites. Jpn J SUrg 13 ; 385-393, 1983

13) Nakase A, Koizumi $T$, Fujita $N$, et al: Studies of the growth and infiltration of experimental tumor of the pancreas in rabbits. Am $j$ Surg $133: 590-592,1977$

14）荁沢正都，永川宅和，上田順彦他：胖癌の進展様 式，特に膵頭神経踥内神経漫潤について，日外会誌 $89: 343,1989$

15）羽生富士夫，今泉俊秀，吉川達也：膵頭部癌におけ 万膵全摘術の適応，消外 $9: 553-560,1986$

16）日本膵臓学会膵癌登録委員会編：全国脺癌登録調 査報告, 1988 年度店例 


\title{
CLINICOPATHOLOGICAL STUDIES ON DUCT CELL CARCINOMA OF THE PANCREAS WITH REFERENCE TO MODE OF OPERATION AND PROGNOSIS
}

\author{
Katsuhiro TAMURA, Masahisa NAKAGAWA, Atsushi NAITO, Seiji YANO, Seikon KIN, \\ Haruhiko NAGAMI, Makoto TERAMOTO, Junichiro KASHIWADA, Yasushi INOUE, \\ Tatsuyuki SESHIMO, Ken UEGAKI and Akira NAKASE \\ First Department of Surgery, Shimane Medical University
}

Twenty-three pancreatectomized cases for pancreatic cancer of duct cell origin were divided into solid type (16 cases) and cystic type (7) by macroscipic tumor form, and clinicopathological studies were done.

Solid tumors, being tubular adenocarcinomas, showed remarkable infiltrative growth with venous, neural and lymphatic invasions, which necessitated the cut margin of the pancreas to be at least $3 \mathrm{~cm}$ distant from macroscopic edge of the tumor. Histological invasion to retropancreatic tissues and regional lymph node involvement were widely observed. Sufficinet dissection of retropancreatic tussues including the extrapancreatic nervous plexus, wide dissection of regional lymph nodes including para-aortic and/or large vascular resection such as portal vein should be performed. On the other hand, cystic tumors, being intraductal papillary carcinomas, cystadenocarcinomas or mucinous adenocarcinomas, showed expansive but non-invasive character.

Postoperative results were poor in solid tumors, and the prognosis was markedly influenced by invasive characters, especially invasions of the intrapancreatic vein and retropancreas including surgical margin. On the contrary, the results were extremely good in cystic tumors. This difference may lie in factors $v$ and rp. Factor ew is a prognosis-regulating factor in macrosopic curative resections for solid tumors. 